\title{
PENERAPAN ANALISIS MULTIDIMENSIONAL SCALING PADA PEMETAAN KARAKTERISTIK KEMISKINAN DI PROVINSI BANTEN
}

\author{
Solikhatun Nafisah ${ }^{1, a)}$ Tabah Heri Setiawan ${ }^{2, b)}$ \\ ${ }^{1}$ Program Studi Matematika FMIPA Universitas Pamulang \\ ${ }^{2}$ Program Studi Matematika FMIPA Universitas Pamulang \\ Email: ${ }^{\text {a) }}$ solikhatun.nafisah@gmail.com ${ }^{\text {b) }}{ }^{\text {tabah.ibnubara@gmail.com }}$
}

\begin{abstract}
The percentage of poverty rates in Indonesia continues to decline, but there are several provinces that have experienced an increase in the percentage of poverty rates, one of which is Banten Province. Poverty alleviation efforts have been carried out by the government so far but in fact that many programs fail to achieve the target. One of the reasons for the failure of programs carried out by the government to overcome poverty problems that occur in the community is the occurrence of equalization or uniformity of policies in each region without first considering that there are characteristics of poverty varying in each region. Mapping the characteristics of poverty needs to be done in order to know what characteristics affect poverty in each region so can help the government in adjusting aid. The method used in this study is multidimensional scaling. And the results obtained are in the Tangerang City, South Tangerang City and Cilegon City have a high characteristic proximity X1, X2 and X9, Cilegon City, Serang Regency, Serang City and Tangerang Regency have relatively high X8 characteristics, X10 Characteristics become closest from Pandeglang Regency and Lebak Regency. With a stress value of $11.4 \%$ and $R 2$ of $0.988 \%$, a multidimensional analysis map can be received.
\end{abstract}

Keywords: Banten, poverty, multidimensional scaling

\begin{abstract}
ABSTRAK
Persentase angka kemiskinan di Indonesia secara garis besar mengalami penurunan, meskipun demikian terdapat beberapa provinsi yang mengalami peningkatan angka kemiskinan salah satunya adalah Provinsi Banten. Upaya pengentasan kemiskinan telah dijalankan oleh pemerintah selama ini namun dalam kenyataannya masih banyak program yang gagal mencapai sasaran. Salah satu penyebab kegagalan program pengentasan kemiskinan diantaranya adalah adanya penyeragaman kebijakan di tiap daerah tanpa memperhatikan terlebih dahulu bahwa terdapat karakteristik kemiskinan berbeda-beda pada setiap daerah. Pemetaan karakteristik kemiskinan perlu dilakukan agar dapat diketahui karakteristik apa saja yang mempengaruhi kemiskinan di setiap daerah sehingga dapat membantu pemerintah dalam penyesuaian bantuan. Dalam penelitian ini metode yang digunakan adalah multidimensional scaling. Adapun hasil yang diperoleh adalah untuk Kota Tangerang, Kota Tangerang selatan dan Kota Cilegon mempunyai kedekatan karakteristik X1, X2 dan X9 yang cukup tinggi, Kota Cilegon, Kabupaten Serang, Kota Serang dan Kabupaten Tangerang mempunyai kedekatan karakteristik X8 yang relatif tinggi, Karakter X10 menjadi karakteristik terdekat dari Kabupaten Pandeglang dan Kabupaten Lebak. Dengan nilai stress sebesar 11,4\% dan $\mathrm{R}^{2}$ sebesar $0,988 \%$ menunjukkan peta analisis multidimensional dapat diterima.
\end{abstract}

Kata kunci: Banten, kemiskinan, multidimensional scaling 


\section{PENDAHUluan}

Indonesia adalah salah satu negara di Asia Tenggara yang penuh dengan kekayaan alam serta dilintasi oleh garis khatulistiwa dan terletak diantara benua Asia dan Australia ini merupakan negara kepulauan yang memiliki keragaman budaya, suku bangsa, ras, agama, kepercayaan, bahasa daerah, dan masih banyak lainnya. Dengan 17.504 pulau yang dimilikinya, menjadikan Indonesia sebagai negara kepulauan terbesar di dunia dengan julukan Nusantara.

Populasi penduduknya mencapai 270.054.853 jiwa pada awal tahun 2018. Jumlah tersebut menjadikan negara ini menjadi negara berpenduduk terbesar keempat di dunia. Hal tersebut menjadi tanggungjawab besar bagi pemerintah untuk menyejahterakan seluruh masyarakatnya. Banyak permasalahan-permasalah yang masih menjadi PR bagi pemerintah dalam meningkatkan kesejahteraan masyarakat, salah satunya adalah masalah yang merupakan masalah utama bukan hanya di Indonesia tapi juga umumnya bagi seluruh negara di dunia lebih khusus di negara berkembang yaitu kemiskinan. Persentase kemiskinan di Indonesia terbilang cukup tinggi yaitu 10,12 persen dari total penduduk atau sekitar 26,582 juta jiwa penduduk. Meskipun dalam beberapa semester terakhir persentase kemiskinan di Indonesia terus mengalami penurunan, namun angka kemiskinan ini masih tergolong cukup tinggi sehingga masalah kemiskinan ini harus terus mendapat perhatian penuh dari pemerintah.

Sebagaimana penjelasan diatas bahwa persentase angka kemiskinan di Indonesia terus mengalami penurunan dalam 6 semester terakhir, namun ada beberapa provinsi yang justru mengalami peningkatan persentase angka kemiskinan. Salah satu provinsi yang mengalami peningkatan persentase angka kemiskinan dalam 3 semester terakhir adalah Provinsi Banten. Provinsi yang mempunyai delapan kota/kabupaten ini adalah pemekaran dari provinsi Jawa Barat pada tahun 2000. Jumlah penduduk miskin di Banten pada bulan September 2016 mencapai 657.740 jiwa atau sekitar 5,36 persen dari total penduduk Banten. Meskipun mengalami penurunan dibandingkan pada bulan Maret 2016, namun pada bulan Maret 2017 mengelami peningkatan sebesar 0,09 persen atau sekitar 17.300 jiwa, dan kemudian terus mangalami peningkatan yang cukup tinggi selama 6 bulan berikutnya yaitu di bulan September 2017 sebesar 0,14 persen atau sekitar 20.790 jiwa. Banyak faktor yang mempengaruhi angka kemiskinan tersebut, diantaranya faktor sosial ekonomi, kesehatan dan faktor pendidikan. Terus meningkatnya angka kemiskinan ini menyebabkan perlunya pemetaan karakteristik kemiskinan sebagai upaya pengentasan kemiskinan agar program maupun paket kebijakan yang diambil oleh pemerintah tepat sasaran.

Berdasarkan uraian diatas, penulis melakukan pemetaan karakteristik kemiskinan di provinsi Banten, sehingga dari hasil analisis yang dilakukan dapat terlihat bagaimana pengelompokan kabupaten/kota di Banten berdasarkan karakteristik kemiskinan yang dimilikinya, dalam penelitian ini menggunakan metode analisis Multidimensional Scaling.

\section{METODOLOGI PENELITIAN}

Jenis penelitian yang digunakan dalam penelitian mengenai pemetaan karakteristik kemiskinan di Provinsi Banten ini adalah applied research (penelitian terapan. Adapun waktu penelitian dilakukan pada bulan April sampai dengan Agustus 2018). Jenis data yang digunakan dalam penelitian ini adalah jenis sekunder. Sumber data yang digunakan dalam penelitian ini adalah data yang sudah dipublikasikan oleh Badan Pusat Statistik (BPS) Provinsi Banten dalam 
website resminya https://banten.bps.go.id/ yaitu data-data dan informasi kemiskinan kab/kota tahun 2017.

Adapun yang dijadikan penelitian adalah seluruh kabupaten dan kota yang ada di Provinsi Banten. Di Provinsi Banten terdapat delapan kabupaten dan kota. Kedelapan kabupaten dan kota tersebut yaitu Kabupaten Pandeglang, Kabupaten Lebak, Kabupaten Tangerang, Kabupaten Serang, Kota Tangerang, Kota Cilegon, Kota Serang dan Kota Tangerang Selatan.

Terdapat sepuluh variabel yang digunakan dalam penelitian ini antara lain angka melek huruf (X1) yaitu persentase penduduk berumur 15 tahun ke atas yang tidak mampu membaca dan menulis huruf latin menurut Kabupaten/kota di Banten, tidak tamat SMA/ sederajat (X2) yaitu persentase penduduk berumur 15 tahun ke atas dengan ijazah tertinggi adalah ijazah Sekolah Dasar (SD) sederajat dan ijazah Sekolah Menengah Pertama (SMP) sederajat serta yang tidak mempunyai ijazah menurut Kabupaten/kota di Provinsi Banten, penduduk sakit dan tidak berobat (X3) yaitu persentase penduduk yang sakit tetapi tidak berobat jalan selama sebulan terakhir dengan alasan tidak mempunyai biaya berobat serta tidak ada biaya dan sarana transportasi menurut Kabupaten/kota di Banten, perempuan yang tidak menggunakan alat KB (X4) yaitu persentase penduduk perempuan berumur 15-49 tahun yang pernah kawin dan tidak menggunakan alat KB menurut Kabupaten/kota di Banten, status kepemilikan bangunan (X5) yaitu persentase rumah tangga dengan status kepemilikan bangunan bukan milik sendiri dan dinas pada tahun 2017, jenis bahan bangunan rumah (X6) adalah persentase rumah tangga menurut jenis dinding pada tahun 2017, fasilitas tempat buang air besar (X7) adalah persentase rumah tanga yang tidak memiliki fasilitas tempat buang air besar pada tahun 2017, tingkat pengangguran terbuka (X8) yaitu persentase jumlah pengangguran terhadap jumlah angkatan kerja pada tahun 2017, jumlah anak yang dilahirkan 5 anak atau lebih (X9) adalah persentase penduduk perempuan berumur 15-49 tahun yang pernah kawin dan memiliki 5 anak atau lebih yang masih hidup pada tahun 2017 dan yang terakhir adalah usia pernikahan $<=16$ tahun (X10) yaitu persentasi penduduk yang perkawinan pertamanya berkisar usia 10-16 tahun.

Teknis analisi data dalam penelitian ini adalah sebagai berikut :

1. Mendeskripsikan data yang diperoleh dimana baris adalah objek penelitian atau kabupaten/kota dan kolom merupakan karakteristik atau variabel kemiskinan.

2. Menentukan nilai kemiripan antar objek ke dalam bentuk matriks jarak D dengan menggunakan rumus jarak Euclidean.

$$
D=d_{i j}{ }^{2}=\sum_{k=1}^{p}\left(x_{i k}-x_{j k}\right)^{2}
$$

3. Menentukan matriks hasil kali B menggunakan rumus.

$$
B=-\frac{1}{2}\left(I-\frac{1}{n} V\right) D^{2}\left(I-\frac{1}{2} V\right) \text {. }
$$

4. Menentukan titik koordinat dengan mencari eigen valuedan eigen vector dari matriks B. Membentuk koordinat objek berdasarkan eigen vector yang berkorespondensi dengan eigen value yang dipilih. Koordinat menggunakan rumus $X=V \Lambda^{\frac{1}{2}}$.

5. Menggabungkan konfigurasi MDS objek dan konfigurasi MDS subjek (peubah) dalam satu konfigurasi (space). 
6. Menghitung disparaties $\widehat{D}$ yang merupakan jarak euclidean dari koordinat terbentuk menggunakan rumus

$$
d_{i j}^{2}=\sum_{k=1}^{p}\left(x_{i k}-x_{j k}\right)^{2}
$$

7. Menguji validitas stimulus koordinat dengan menghitung nilai stress menggunakan rumus

$$
\text { Stress }=\sqrt{\frac{\sum_{i, j}^{n}\left(d_{i j}-\hat{d}_{i j}\right)^{2}}{\sum_{i, j}^{n}\left(d_{i j}-\bar{d}\right)^{2}}}
$$

8. dan menghitung nilai $R^{2}$ dengan menggunakan rumus

$$
R^{2}=1-\frac{\sum_{i, j}^{n}\left(d_{i j}-\hat{d}_{i j}\right)^{2}}{\sum_{i, j}^{n}\left(d_{i j}-\bar{d}\right)^{2}}
$$

\section{HASIL DAN PEMBAHASAN}

\subsection{Hasil Penelitian}

Data penelitian yang diambil adalah data sekunder. Sumber data yang digunakan dalam penelitian ini adalah data yang sudah dipublikasikan oleh Badan Pusat Statistik (BPS) Provinsi Banten dalam website resminya https://banten.bps.go.id/ yaitu data-data dan informasi kemiskinan kabupaten/kota tahun 2017. Adapun data yang diperoleh adalah sebagai berikut :

Tabel 3.1 Data karakteristik kemiskinan di Provinsi Banten tahun 2017

\begin{tabular}{lcccccccccc}
\hline Kabupaten/Kota & $\mathbf{X 1}$ & $\mathbf{X 2}$ & $\mathbf{X 3}$ & $\mathbf{X 4}$ & $\mathbf{X 5}$ & $\mathbf{X 6}$ & $\mathbf{X 7}$ & $\mathbf{X 8}$ & $\mathbf{X 9}$ & $\mathbf{X 1 0}$ \\
\hline Kab Pandeglang & 4,57 & 83,22 & 10,53 & 23,61 & 8,22 & 43,34 & 35,92 & 8,3 & 8,27 & 25,04 \\
Kab Lebak & 3,79 & 88,1 & 10,14 & 17,83 & 6,13 & 34,2 & 30,47 & 8,88 & 6,04 & 26,07 \\
Kab Tangerang & 4,08 & 68,88 & 3,9 & 34,89 & 16,05 & 8,92 & 7,3 & 10,57 & 2,46 & 12,57 \\
Kab Serang & 4,64 & 76,5 & 10,38 & 31,69 & 8,83 & 12,51 & 24,19 & 13 & 7,52 & 19,45 \\
Kota Tangerang & 1,78 & 46,77 & 1,88 & 39,23 & 39,41 & 3,09 & 0,31 & 7,16 & 0,99 & 9,2 \\
Kota Cilegon & 4,04 & 54,12 & 5,06 & 28,77 & 26,16 & 1,95 & 6,14 & 11,88 & 4,69 & 15,04 \\
Kota Serang & 5,24 & 65,74 & 3,43 & 32,84 & 18,65 & 2,07 & 14,81 & 8,43 & 6,64 & 20,79 \\
Kota Tangerang & 1,46 & 34,55 & 0,97 & 36,6 & 16,18 & 0,73 & 0,11 & 6,83 & 1,87 & 7,65 \\
Selatan & & & & & & & & &
\end{tabular}

Dimana X1 untuk karakteristik kemiskinan angka melek huruf, X2 untuk karakteristik kemiskinan penduduk tidak tamat SMA/ sederajat, X3 untuk karakteristik kemiskinan penduduk sakit dan tidak berobat, $\mathrm{X} 4$ untuk karakteristik kemiskinan perempuan yang tidak menggunakan alat KB, X5 untuk karakteristik kemiskinan status kepemilikan bangunan, X6 untuk karakteristik kemiskinan jenis bahan bangunan rumah, $\mathrm{X} 7$ untuk karakteristik kemiskinan fasilitas buang air besar, X8 untuk karakteristik kemiskinan tingkat pengangguran terbuka, X9 untuk karakteristik kemiskinan jumlah anak yang dilahirkan 5 anak atau lebih dan X10 untuk karakteristik kemiskinan usia pernikahan 16 tahun kebawah. 


\subsubsection{Deskripsi Data Karakteristik Kemiskinan}

Deskriptif dari masing-masing variabel penelitian atau karakteristik kemiskinan kabupaten/kota di Provinsi Banten tahun 2017 diperoleh hasil sebagai berikut :

Tabel 3.2 Tabel diskriptif karakteristik kemiskinan angka melek huruf (X1) tiap kabupaten/kota di Provinsi Banten tahun 2017

\begin{tabular}{ll}
\hline \multicolumn{1}{c}{ Summary } & X1 \\
\hline Minimal & 1,460 \\
Kuartil 1 & 3,288 \\
Median & 4,060 \\
Mean & 3,700 \\
Kuartil 3 & 4,588 \\
Maksimal & 5,240 \\
\hline
\end{tabular}

Pada Tabel 3.2 diketahui nilai minimal dan maksimal karakteristik kemiskinan angka melek huruf (X1) pada tiap kabupaten/kota di Provinsi Banten yaitu masing-masing 1,460 untuk Kota Tangerang Selatan dan 5,240 untuk Kota Serang, sedangkan untuk nilai rata-ratanya adalah 3,70 .

Tabel 3.3 Tabel diskriptif karakteristik kemiskinan penduduk yang tidak tamat SMA/sederajat (X2) tiap kabupaten/kota di Provinsi Banten tahun 2017

\begin{tabular}{lc}
\hline \multicolumn{1}{c}{ Summary } & X2 \\
\hline Minimal & 34,55 \\
Kuartil 1 & 52,28 \\
Median & 67,31 \\
Mean & 64,73 \\
Kuartil 3 & 78,18 \\
Maksimal & 88,10 \\
\hline
\end{tabular}

Pada Tabel 3.3 diketahui nilai maksimal dan minimal pada karakteristik kemiskinan penduduk yang tidak tamat SMA/ sederajat (X2)tiap kabupaten/kota di Provinsi Banten masingmasing adalah 34,55 untuk Kota Tangerang Selatan dan 88,10 untuk Kab Lebak, sedangkan untuk nilai rata-ratanya adalah 64,73 .

Tabel 3.4 Tabel diskriptif karakteristik kemiskinan penduduk sakit dan tidak berobat (X3) tiap kabupaten/kota di Provinsi Banten tahun 2017

\begin{tabular}{lr}
\hline \multicolumn{1}{c}{ Summary } & \multicolumn{1}{c}{ X3 } \\
\hline Minimal & 0,970 \\
Kuartil 1 & 3,042 \\
Median & 4,480 \\
Mean & 5,786 \\
Kuartil 3 & 10,200 \\
Maksimal & 10,530 \\
\hline
\end{tabular}




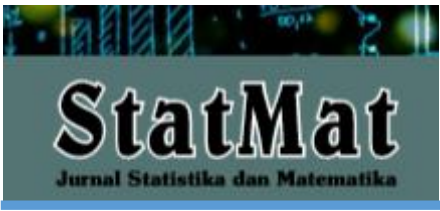

P-ISSN: 2655-3724

STATMAT (Jurnal Statistika dan Matematika), Vol. 1, No. 2, Juli 2019

Halaman: 46-59

@Prodi S-1 Matematika FMIPA Unpam

Pada Tabel 3.4 diketahui nilai minimal dan maksimal pada karakteristik kemiskinan penduduk sakit dan tidak berobat (X3) tiap kabupaten/kota di Provinsi Banten diketahui masingmasing adalah 0,97 untuk Kota Tangerang Selatan dan 10,53 untuk Kab pandeglang, sedangkan untuk nilai rata-ratanya adalah 5,786.

Tabel 3.5 Tabel diskriptif karakteristik kemiskinan perempuan yang tidak menggunakan alat KB (X4) tiap kabupaten/kota di Provinsi Banten tahun 2017

\begin{tabular}{ll}
\hline \multicolumn{1}{c}{ Summary } & X4 \\
\hline Minimal & 17,83 \\
Kuartil 1 & 27,48 \\
Median & 32,27 \\
Mean & 30,68 \\
Kuartil 3 & 35,32 \\
Maksimal & 39,23 \\
\hline
\end{tabular}

Pada Tabel 3.5 diketahui nilai maksimal dan minimal pada karakteristik kemiskinan perempuan yang tidak menggunakan alat KB (X4) tiap kabupaten/kota di Provinsi Banten masing-masing adalah 17,83 untuk Kab Lebak dan 39,23 untuk Kota Tangerang, sedangkan untuk nilai rata-ratanya adalah 30,68 .

Tabel 3.6 Tabel diskriptif karakteristik kemiskinan status kepemilikan bangunan (X5) tiap kabupaten/kota di Provinsi Banten tahun 2017

\begin{tabular}{lr}
\hline \multicolumn{1}{c}{ Summary } & \multicolumn{1}{c}{ X5 } \\
\hline Minimal & 6,130 \\
Kuartil 1 & 8,678 \\
Median & 16,115 \\
Mean & 17,454 \\
Kuartil 3 & 20,527 \\
Maksimal & 39,410 \\
\hline
\end{tabular}

Pada Tabel 4.6 diketahui nilai maksimal dan minimal pada karakteristik kemiskinan status kepemilikan bangunan (X5) tiap kabupaten/kota di Provinsi Banten masing-masing adalah 6,13 untuk Kab Lebak dan 39,41 untuk Kota Tangerang, sedangkan untuk nilai rata-ratanya adalah 17,454 .

Tabel 3.7 Tabel diskriptif karakteristik kemiskinan jenis bahan bangunan rumah (X6) tiap kabupaten/kota di Provinsi Banten tahun 2017

\begin{tabular}{lr}
\hline \multicolumn{1}{c}{ Summary } & \multicolumn{1}{c}{ X6 } \\
\hline Minimal & 0,730 \\
Kuartil 1 & 2,040 \\
Median & 6,005 \\
Mean & 13,351 \\
Kuartil 3 & 17,933 \\
Maksimal & 43,340 \\
\hline
\end{tabular}


Pada Tabel 3.7 diketahui nilai maksimal dan minimal pada karakteristik kemiskinan jenis bahan bangunan rumah (X6) tiap kabupaten/kota di Provinsi Banten masing-masing adalah 0,73 untuk Kota Tangerang Selatan dan 43,34 untuk Kab Pandeglang, sedangkan untuk nilai rataratanya adalah 13,351 .

Tabel 3.8 Tabel diskriptif karakteristik kemiskinan fasilitas buang air besar (X7) tiap kabupaten/kota di Provinsi Banten tahun 2017

\begin{tabular}{lr}
\hline \multicolumn{1}{c}{ Summary } & \multicolumn{1}{c}{ X7 } \\
\hline Minimal & 0,110 \\
Kuartil 1 & 4,683 \\
Median & 11,055 \\
Mean & 14,906 \\
Kuartil 3 & 25,760 \\
Maksimal & 35,920 \\
\hline
\end{tabular}

Pada Tabel 3.8 diketahui nilai maksimal dan minimal pada karakteristik kemiskinan fasilitas buang air besar (X7) tiap kabupaten/kota di Provinsi Banten masing-masing adalah 0,11 untuk Kota Tangerang Selatan dan 35,92 untuk Kab Pandeglang, sedangkan untuk nilai rataratanya adalah 14,906

Tabel 3.9 Tabel diskriptif karakteristik kemiskinan tingkat pengangguran terbuka (X8) tiap kabupaten/kota di Provinsi Banten tahun 2017

\begin{tabular}{lr}
\hline \multicolumn{1}{c}{ Summary } & \multicolumn{1}{c}{ X8 } \\
\hline Minimal & 6,830 \\
Kuartil 1 & 8,015 \\
Median & 8,655 \\
Mean & 9,381 \\
Kuartil 3 & 10,898 \\
Maksimal & 13,000 \\
\hline
\end{tabular}

Pada Tabel 3.9 diketahui nilai maksimal dan minimal pada karakteristik kemiskinan tingkat pengangguran terbuka (X8) tiap kabupaten/kota di Provinsi Banten masing-masing adalah 6,83 untuk Kota Tangerang Selatan dan 13,00 untuk Kab Serang, sedangkan untuk nilai rata-ratanya adalah 9,381 .

Tabel 3.10 Tabel diskriptif karakteristik kemiskinan jumlah anak yang dilahirkan 5 anak atau lebih (X9) tiap kabupaten/kota di Provinsi Banten tahun 2017

\begin{tabular}{lc}
\hline \multicolumn{1}{c}{ Summary } & X9 \\
\hline Minimal & 0,990 \\
Kuartil 1 & 2,312 \\
Median & 5,365 \\
Mean & 4,810 \\
Kuartil 3 & 6,860 \\
Maksimal & 8,270 \\
\hline
\end{tabular}


Pada Tabel 3.10 diketahui nilai maksimal dan minimal pada karakteristik kemiskinan jumlah anak yang dilahirkan 5 anak atau lebih (X9) tiap kabupaten/kota di Provinsi Banten masing-masing adalah 0,99 untuk Kota Tangerang dan 8,27 untuk Kab Pandeglang, sedangkan untuk nilai rata-ratanya adalah 4,81 .

Tabel 3.11 Tabel diskriptif karakteristik kemiskinan usia pernikahan 16 tahun kebawah (X10) tiap kabupaten/kota di Provinsi Banten tahun 2017

\begin{tabular}{lr}
\hline \multicolumn{1}{c}{ Summary } & \multicolumn{1}{c}{ X10 } \\
\hline Minimal & 7,65 \\
Kuartil 1 & 11,73 \\
Median & 17,25 \\
Mean & 16,98 \\
Kuartil 3 & 21,85 \\
Maksimal & 26,07 \\
\hline
\end{tabular}

Pada Tabel 3.11 diketahui nilai maksimal dan minimal pada karakteristik kemiskinan usia pernikahan 16 tahun kebawah (X10) tiap kabupaten/kota di Provinsi Banten masing-masing adalah 7,65 untuk Kota Tangerang Selatan dan 26,07 untuk Kab Lebak, sedangkan untuk nilai rata-ratanya adalah 16,98 .

3.1.2. Menentukan nilai kemiripan (similiarity) antar objek ke dalam bentuk matriks jarak D dengan menggunakan rumus jarak Euclidean.

$$
D=d_{i j}^{2}=\sum_{k=1}^{p}\left(x_{i k}-x_{j k}\right)^{2}
$$

Adapun nilai kemiripan dapat diubah ke dalam bentuk matriks $D$ :

$$
D_{8 x 8}=\left[\begin{array}{cccccc}
0 & 13.48939 & 51.34813 & 35.39529 & \ldots & 78.39284 \\
13.48939 & 0 & 46.60182 & 30.12662 & \ldots & 76.24496 \\
51.34813 & 46.60182 & 0 & 23.23230 & \ldots & 36.80018 \\
35.39529 & 30.12662 & 23.23230 & 0 & \cdots & 53.52046 \\
\vdots & \vdots & \vdots & \vdots & \ddots & \vdots \\
78.39284 & 76.24496 & 36.80018 & 53.52046 & \cdots & 0
\end{array}\right]
$$

Berdasarkan matriks data $D$ diatas menunjukkan bahwa jarak terdekat diantara kabupaten/kota di Provinsi Banten adalah Kab Pandeglang dan Kab Lebak dengan jarak sebesar 13,48939. Hal ini menunjukkan bahwa Kab Pandeglang dan Kab Lebak memiliki kemiripan karakteristik kemiskinan. Sedangkan Kab Pandeglang dan Kota Tangerang selatan memiliki jarak terjauh diantara kabupaten/kota lainnya yaitu dengan jarak sebesar 78,39284.

\subsubsection{Menentukan Matriks:}

$$
B=-\frac{1}{2}\left(I-\frac{1}{n} V\right) D^{2}\left(I-\frac{1}{n} V\right)
$$

diperoleh matriks product scalar B sebagai berikut: 


$$
B_{8 \times 8}=\left[\begin{array}{cccccc}
0 & -1.421591 & -20.59867 & -9.787709 & \cdots & -48.011230 \\
-1.421591 & 0 & -16.96664 & -7.090730 & \cdots & -45.416359 \\
-20.59867 & -16.96664 & 0 & -4.216718 & \cdots & -10.58010 \\
-9.787709 & -7.090730 & -4.216718 & 0 & \cdots & -22.37843 \\
\vdots & \vdots & \vdots & \vdots & \ddots & \vdots \\
-48.011230 & -45.416359 & -10.58010 & -22.37843 & \cdots & 0
\end{array}\right]
$$

3.1.4. Menentukan titik koordinat dengan mencari eigen value dan eigen vector dari matriks B Untuk mencari nilai eigen dan vektor eigen dapat dituliskan $B x=\lambda x$ sebagai:

$$
\begin{gathered}
A x=\lambda I x \\
B x=\lambda I x \\
\Leftrightarrow(\lambda I-B) x=0
\end{gathered}
$$

Dengan menggunakan program $\mathrm{R}$, nilai eigen dan vektor eigen dari matriks $\mathrm{B}$ adalah sebagai berikut :

a. Nilai Eigen (eigen value)

$$
\begin{gathered}
\lambda_{1}=98.7230482 \\
\lambda_{2}=18.7757854 \\
\lambda_{3}=5.8201181 \\
\vdots \\
\lambda_{8}=-127.7452689
\end{gathered}
$$

b. Vektor Eigen (eigen vector)

$$
X=\left[\begin{array}{ccccc}
0.51943516 & -0.28512224 & -0.071743674 & \cdots & -0.4723612 \\
0.48374743 & -0.03333419 & -0.014283212 & \cdots & -0.4308953 \\
-0.09941881 & 0.44546452 & 0.002234022 & \cdots & -0.2172779 \\
\vdots & \vdots & \vdots & \ddots & \vdots \\
-0.44752198 & -0.33335889 & 0.700104556 & \cdots & -0.4398477
\end{array}\right]
$$

Dalam penentuan jumlah dimensi pada analisis multidimensional scaling, didasarkan pada eigen value. Dengan eigen value positif terbesar secara berurutan $\lambda_{1}>\lambda_{2}>\lambda_{3}>\ldots>\lambda_{n}$ yang dapat dipilih untuk menentukan jumlah dimensi. Untuk memudahkan dalam menginterpretasi hasil multidimensional scaling, pada umumnya jumlah dimensi yang digunakan adalah 2 dimensi. Oleh karena itu, eigen value positif yang pertama dari matriks B yaitu $\lambda 1=98.72305$ dan $\lambda 2=$ 18.77579 .

Selanjutnya menentukan titik koordiat dapat dilakukan dengan mengambil vektor eigen yang berkorespondensi dengan 2 eigen value yang dipilih. 
Tabel 3.12 Titik koordinat untuk 2 dimensi

\begin{tabular}{lrr}
\hline \multicolumn{1}{c}{ Kabupaten/Kota } & \multicolumn{1}{c}{ X } & \multicolumn{1}{c}{ Y } \\
\hline Kab Pandeglang & $-42,22449$ & 11,110802 \\
Kab Lebak & $-3,80857$ & 1,556567 \\
Kab Tangerang & 5,02202 & $-5,969648$ \\
Kab Serang & $-14,38651$ & $-10,109059$ \\
Kota Tangerang & 32,99116 & 7,142559 \\
Kota Cilegon & 18,55860 & $-1,490689$ \\
Kota Serang & 5,21842 & $-9,699457$ \\
Kota Tangerang Selatan & 34,62938 & 7,458925 \\
\hline
\end{tabular}

3.1.5. Menghitung matriks $\hat{D}$ yang merupakaj jarak Euclidean dari koordinat yang terbentuk.

Jarak objek dalam ruang dimensi tersebut dihitung menggunakan koordinat yang terbentuk. Tiap-tiap jarak dihitung dengan menggunakan rumus jarak euclid. Jarak yang dihasilkan dapat dilihat pada matriks $\hat{D}$ sebagai berikut :

$$
\hat{D}_{8 \times 8}=\left[\begin{array}{cccccc}
0 & 9.854953 & 50.239177 & 35.003368 & \cdots & 76.940586 \\
9.854953 & 0 & 45.457956 & 27.970840 & \cdots & 74.671586 \\
50.239177 & 45.457956 & 0 & 19.845046 & \cdots & 32.510339 \\
35.003368 & 27.970840 & 19.845046 & 0 & \cdots & 52.069102 \\
\vdots & \vdots & \vdots & \vdots & \ddots & \vdots \\
76.940586 & 74.671586 & 32.510339 & 52.069102 & \cdots & 0
\end{array}\right]
$$

Berdasarkan matriks data diatas menunjukkan bahwa jarak terdekat diantara kabupaten/kota di Provinsi Banten adalah Kota Tangerang dan Kota Tangerang Selatan dengan jarak sebesar 1,668484. Sedangkan Kab Pandeglang dan Kota Tangerang selatan memiliki jarak terjauh diantara kabupaten. Kota lainnya yaitu dengan jarak sebesar 76,940586.

3.1.6. Menggabungkan konfigurasi MDS objek dan konfigurasi MDS subjek (peubah) dalam satu konfigurasi (space)

Berdasarkan titik koordinat yang sudah diperoleh pada Tabel 4.12 maka diperoleh perceptual map sebagai berikut : 


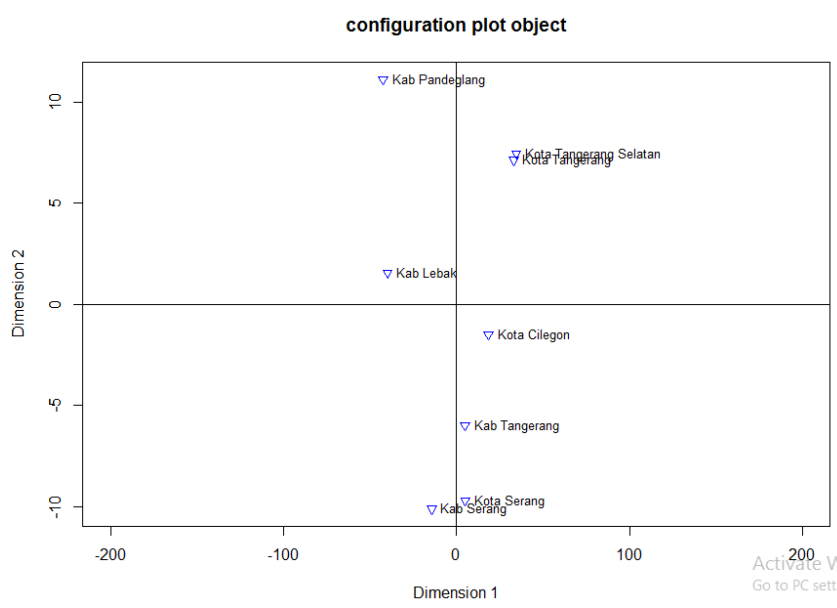

Gambar 3.1 Hasil penskalaan 2 dimensi untuk setiap objek penelitian (kabupaten/kota) dalam satu konfigurasi

Berikut hasil perceptual map hubungan antara kelompok objek kemiripan dengan dengan variabel/ karakteristik kemiskinan.

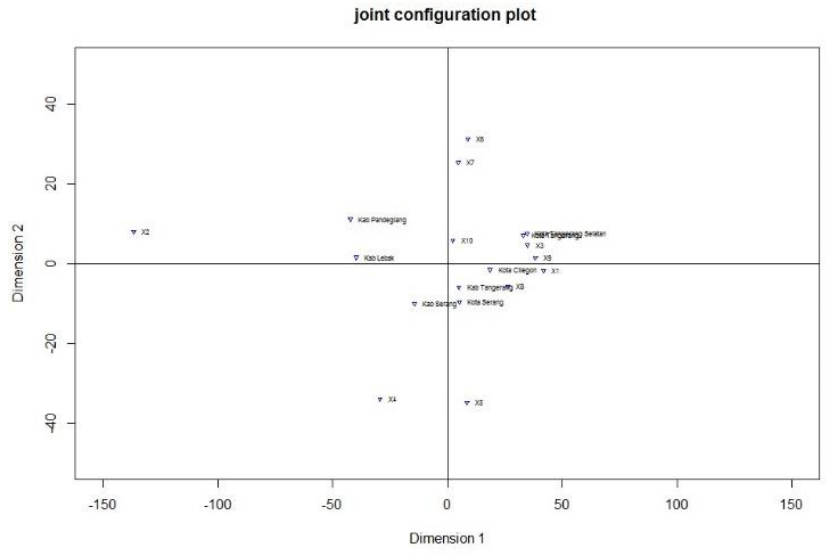

Gambar 3.2 Hasil penskalaan 2 dimensi untuk setiap objek penelitian (kabupaten/kota) beserta karakteristik kemiskinan dalam satu konfigurasi.

Pada Gambar 3.2 dapat dilihat dengan jelas posisi seluruh objek dan variabel. Informasi ini digunakan untuk menentukan karakteristik kemiskinan di setiap kabupaten/kota. Suatu kabupaten/kota yang terletak berdekatan dengan karakteristik kemiskinan mempengaruhi kabupaten/kota tersebut.

3.1.7. Menguji validitas stimulus koordinat dengan menghitung nilai stress dan nilai $R^{2}$.

a. Nilai Stress

Cara menghitung stress adalah menggunakan rumus :

$$
\text { Stress }=\sqrt{\frac{\sum_{i, j}^{n}\left(d_{i j}-\hat{d}_{i j}\right)^{2}}{\sum_{i, j}^{n}\left(d_{i j}-\bar{d}\right)^{2}}}
$$

Nilai stress yang diperoleh adalah 0,114 atau sebesar 11,4\%. Nilai tersebut menunjukkan bahwa perceptual map atau model penskalaan yang dihasilkan termasuk kriteria cukup baik. 


\section{b. Nilai $R^{2}$}

Dalam metode multidimensional scaling, semakin tinggi nilai $R^{2}$ menunjukkan bahwa semakin tepatnya mewakili data input. Percentual map atau peta spatial dapat diterima jika nilai $R^{2} \geq 0,6$. Nilai $R^{2}$ dapat diperoleh dengan rumus :

$$
R^{2}=1-\frac{\sum_{i, j}^{n}\left(d_{i j}-\hat{d}_{i j}\right)^{2}}{\sum_{i, j}^{n}\left(d_{i j}-\bar{d}\right)^{2}}
$$

Nilai $R^{2}$ yang diperoleh adalah sebesar 0,988. Nilai ini menunjukkan bahwa perta spatial (perceptual map) sudah dapat diterima.

\subsection{Pembahasan}

Multidimensional scaling merupakan metode analisis multivariate yang berhubungan dengan pembuatan peta untuk menggambarkan posisi sebuah obyek dengan obyek lainnya berdasarkan kemiripan obyek-obyek tersebut. Berdasarkan hasil penelitian yang sudah dijabarkan diatas, diperoleh map spatial atau perceptual map yang sudah dapat diterima. Untuk melihat kecocokan apakah map spatial yang diperoleh baik atau tidak, dapat dilihat dari nilai stress dan nilai $R^{2}$. Nilai stress yang diperoleh adalah 0,114 atau $11,4 \%$ yang menunjukkan bahwa kategori map spatial cukup baik. Kemudian nilai $R^{2}$ yang diperoleh adalah $0,988 \geq 0,6$ yang menunjukkan bahwa map spatial yang dihasilkan sudah dapat diterima.

Terdapat 2 map spatial yang dihasilkan dalam analisis multidimensional scaling. Pada gambar 3.1 mengindikasikan kedekatan antar objek penelitian dalam hal ini kabupaten/ kota di provinsi Banten. Dua objek atau lebih yang memiliki kemiripan karakteristik kemiskinan ditunjukkan dengan kedekatan titik objek pada map spatial. Semakin dekat titik antar objek maka menunukkan kemiripan, sebaliknya semakin jauh titik antar objek maka menunjukkan ketidakmiripan antar objek-objek tersebut. Berdasarkan gambar 3.1 kabupaten/kota yang memiliki kemiripan dilihat dari kedekatan titiknya adalah Kota Tangerang dan Kota Tangerang Selatan, Kota Serang dan Kab Serang, serta Kota Cilegon dan Kab Tangerang.

Sedangkan map spatial pada gambar 3.2 dapat dilihat objek penelitian atau kabupaten/ kota di provinsi Banten dengan variabel kemiskinan yang mempunyai jarak yang berdekatan. Dalam map spatial ini masing-masing kabupaten/ kota mempunyai karakteristik kemiskinan yang dominan. Berdasarkan jarak objek dengan variabel dapat dijelaskan Kota Tangerang, Kota Tangerang selatan dan Kota Cilegon memiliki kedekatan dengan karakteristik persentase penduduk berumur 15 tahun ke atas yang tidak mampu membaca dan menulis huruf latin (X1), karakteristik persentase penduduk yang sakit tetapi tidak berobat jalan selama sebulan terakhir dengan alasan tidak mempunyai biaya berobat serta tidak ada biaya dan sarana transportasi menurut Kabupaten/ Kota di Banten (X3), dan karakteristik persentase penduduk perempuan berumur 15-49 tahun yang pernah kawin dan memiliki5 anak atau lebih yang masih hidup (X9). Kota Cilegon, Kabupaten Serang, Kota Serang dan Kabupaten Tangerang memiliki jarak yang relative dekat dengan karakteristik persentase jumlah pengangguran terhadap jumlah angkatan kerja (X8). Karakteristik dengan jarak terdekat dengan Kabupaten Pandeglang dan Kabupaten Lebak adalah karakteristik persentasi penduduk yang perkawinan pertamanya berkisar usia 10-16 tahun (X10). 
Selain penjelasan diatas, beberapa informasi yang dapat diperoleh dari gambar 3.2 adalah beberapa karakteristik terletak jauh dari objek atau kabupaten/ kota di provinsi Banten. Karakteristik tersebut antara lain adalah persentase penduduk berumur 15 tahun ke atas dengan ijazah tertinggi adalah ijazah Sekolah Dasar (SD) sederajat dan ijazah Sekolah Menengah Pertama (SMP) sederajat serta yang tidak mempunyai ijazah (X2), persentase penduduk perempuan berumur 15-49 tahun yang pernah kawin dan tidak menggunakan alat KB (X4), persentase rumah tangga dengan status kepemilikan bangunan bukan milik sendiri dan dinas (X5), persentase rumah tangga menurut jenis dinding (X6) dan persentase rumah tanga yang tidak memiliki fasilitas tempat buang air besar (X7). Jarak yang jauh dapat dikatakan bahwa karakteristik yang mempunyai pengaruh untuk kabupaten/ kota di provinsi Banten.

\section{KESIMPULAN DAN SARAN}

\subsection{Kesimpulan}

Berdasarkan hasil penelitian dan pembahasan yang sudah dijabarkan dalam bab sebeumnya, dapat disimpulkan sebagai berikut :

1. Dilihat dari gambar 3.1 dan gambar 3.2, Kota Tangerang, Kota Tangerang selatan dan Kota Cilegon memiliki kedekatan dengan karakteristik persentase penduduk berumur 15 tahun ke atas yang tidak mampu membaca dan menulis huruf latin (X1), karakteristik persentase penduduk yang sakit tetapi tidak berobat jalan selama sebulan terakhir dengan alasan tidak mempunyai biaya berobat serta tidak ada biaya dan sarana transportasi menurut Kabupaten/ Kota di Banten (X3), dan karakteristik persentase penduduk perempuan berumur 15-49 tahun yang pernah kawin dan memiliki 5 anak atau lebih yang masih hidup (X9). Kota Cilegon, Kabupaten Serang, Kota Serang dan Kabupaten Tangerang memiliki jarak yang relatif dekat dengan karakteristik persentase jumlah pengangguran terhadap jumlah angkatan kerja (X8). Karakteristik dengan jarak terdekat dengan Kabupaten Pandeglang dan Kabupaten Lebak adalah karakteristik persentasi penduduk yang perkawinan pertamanya berkisar usia 10-16 tahun (X10)

2. Nilai stress yang diperoleh adalah 0,114 atau $11,4 \%$ yang menunjukkan bahwa kategori map spatial cukup baik. Kemudian nilai $R^{2}$ yang diperoleh adalah $0,988 \geq 0,6$ yang menunjukkan bahwa map spatial yang dihasilkan sudah dapat diterima.

\subsection{Saran}

Adapun untuk penelitian selanjutnya mengenai analisis kemiskinan dapat dilakukan dengan jangkauan wilayah yang lebih luas. Dapat menggunakan metode multidimensional scaling maupun dengan metode analisis multivariat yang lainnya.

Mengenai program yang digunakan, bagi pemula yang baru menggunakan program $\mathrm{R}$, sebelum menggunakan program pastikan mengunduh beberapa fungsi pendukung terlebih dahulu karena perhitungan analisis (dalam hal ini multidimensional scaling), fungsi-fungsi yang digunakan tidak secara langsung tersedia dalam menu program. Mengunduh beberapa fungsi dapat dilakukan dengan memilih menu packages dan pilih install package(s). 


\section{DAFTAR PUSTAKA}

BPS. (2017). Statistik Kesejahteraan Rakyat Provinsi Banten. Jakarta: BPS.

BPS. (2018). Analisis dan Perhitungan Tingkat Kemiskinan 2008. Jakarta: BPS.

BPS. (2018). Keadaan Angkatan Kerja Provinsi Banten. Tangerang: BPS.

Brown, B. L., Hendrix, S. B., Hedges, D. W., \& Smith, T. B. (2012). Multivariate Analysis For The Biobehavioral And Social Sciences. New Jersey: John Wiley \& Sons, Inc.

Iskandar, A., \& Subekan, A. (2016, Juni). Analisis Determinan Kemiskinan Di Sulawesi Selatan. Tata Kelola \& Akuntabilitas Keuangan Negara, 2(1), 1-26. doi:10.28986/jtaken.v2i1.36

Johnson, R. A., \& Wichern, D. W. (2017). Applied Multivariate Statistical Analysis, 6th Ed. New Jersey: Prentice Hall Inc.

Julita, N. (2016, April). Penerapan Metode Multidimensional Scaling dalam Pemetaan Sarana Kesehatan di Jawa Barat. Jurnal Matematika Integratif, 12(1), 43-50. doi:10.24198/jmi.v12.n1.10283.43-50

Mattjik, A. A., \& Sumertajaya, I. M. (2011). Sidik Peubah Ganda dengan Menggunakan SAS. Bogor: IPB Press.

Sa'diyah, Y. H., \& Arianti, F. (2012). Analisis Kemiskinan Rumah Tangga Melalui FaktorFaktor yang Mempengaruhinya di Kecamatan Tugu Kota Semarang. Diponegoro Journal of Economics, 1(1), 1-11. Diambil kembali dari https://ejournal3.undip.ac.id/index.php/jme/article/view/249/254

Santoso, S. (2000). Penerapan Metode Multidimensional Scaling (MDS) dalam Perencanaan Formulasi Strategi Pemasaran Supermarket Hero Malang. Optimum, 1(1), 60-70. doi:10.22219/JTIUMM.Vol1.No1.60-70

Santoso, S. (2017). Statistik Multivariat dengan SPSS. Jakarta: PT Gramedia. 